appreciation of the importance of forestry in the rural areas of the deep South as a result of the growth there of the pulp industry. As usual in such volumes, agriculture gets disproportionate attention in comparison with forestry. This is carried to an intolerable extreme in the chapter on California. The important forest resources of this state are totally neglected. Even though her vast agricultural wealth and fast-growing non-forest industrial might do tend to dwarf the forest products industry, the annual timber cut in California has been second only to that of Oregon for a number of years since World War II. In addition to this by no means negligible forest products industry, the aesthetic, recreational, and watershed protection values of California's forest lands are incalculable. The general coverage the author may have felt sufficient in the chapter on "Mountain and Desert" for all the western states cannot be considered an adequate substitute, since forests and their influence in California are rather unique, at least in North America.

As a framework for understanding the role of physical and economic geography in land use on a broad scale, this book should prove useful to the general forester, but it contains little of direct technical value for the forest research worker who seeks special information on forest geography. On the whole, this volume has comparatively few faults and these may be considered minor in view of the book's overall value. No doubt in this latest edition it will continue to serve a valuable role both as a reference and textbook.

P. G. HADDOCK

\title{
Harvesting Timber Crops
}

Second Edition, 1966. McGraw-Hill Co. of Canada Ltd., 330 Progress Ave., Scarborough, Ont. $540 \mathrm{pp}$.

The book describes wood harvesting in Canada and the United States in 16 chapters of some 500 pages. Two of the three co-authors are professors in forestry schools; Wackerman from Duke University, and Michell from the University of Toronto. Hagenstein is with the Industrial Forestry Association (U.S.A.). The book is intended to serve as a text in logging background for university students. Others, such as equipment distributors, who deal with the logging industry, and who have not had a logging background, would also find it rewarding reading.

The text covers harvesting in four parts: the forest as a wood source for cropping, processing of trees into merchantable forms, handling and transportation, and organizational control of logging operations. The first part contains a good account of the evolution of the North American logging industry and its harvesting methods. The planning of a forest operation is discussed with consideration given to external controlling factors such as safety regulations, labour working conditions, labour laws, and other forms of legislation.

The second part describes in detail the processing of trees into merchantable forms in about 100 pages of the text. Processing operations discussed include felling, limbing, topping, bucking, and peeling. This part may be a little too detailed for this type of book and almost reads like an instruction book. An example is the section on bucking. 
The third part covers the many forms of handling and transportation very ably. Clearly reproduced photographs are extensively used throughout to illustrate well the varied operations encountered in today's harvesting practices.

The last part includes a chapter on wood measurement along with a discussion of the factors affecting the choice of logging method. The authors have wisely chosen to illustrate the many logging methods by describing, separately, 38 jobs representing all North American areas. Although cost figures are not given, overall production figures and labour content are usually recorded. In addition, about 30 pages are devoted to cost analysis and records. Although this is not a text on logging cost control, this section might be expanded at the expense of some of part two on processing. Finally, a very few pages are devoted to logging techniques and machines still under development, which perhaps does not give the proper perspective to this phase of wood harvesting.

The book concludes with a two-page bibliography. For students, a more liberal use of references could have been made throughout the text to facilitate further study in particular areas.

In general, the criticisms noted above are minor, and the book gives a very good description of modern logging operations. Canadians will find particular satisfaction in the coverage given to this country's logging; something which has been missing heretofore.

D. C. Horncastle 